\title{
ANALISIS MUTU LAYANAN ELECTRONIC DELIVERY CHANNEL TERHADAP KEPUASAN NASABAH (STUDI PADA BNI SYARIAH)
}

\section{ANALYSIS OF ELECTRONIC SERVICE DELIVERY CHANNEL QUALITY ON CUSTOMER SATISFACTION (STUDIES IN BNI SHARIA)}

\author{
Muhammad Idris ${ }^{1 a}$, Rully Trihantana ${ }^{2 b}$ \\ 1aJurusan Ekonomi Islam Fakultas Ekonomi Islam Universitas Djuanda, Jl. Tol Ciawi No. \\ 1, KotakPos 35 Bogor 16720 \\ 2bJurusan Perbankan Syariah Fakultas Ekonomi Islam Universitas Djuanda, Jl. Tol Ciawi \\ No.1, KotakPos 35 Bogor 16720
}

E-mail : 1amuhammad.idris@unida.ac.id, 2brully.trihantana@unida.ac.id

(Diterima oleh Dewan Redaksi: 12-01-2016)

(Dipublikasikan oleh Dewan Redaksi: 01-06-2016)

\begin{abstract}
This study aims to determine the quality of electronic service delivery channels in BNI Syariah Sukabumi. The number of respondents in this study as many as 30 by using a nonprobability sampling techniques. The method used is logistic regression method. The results of analysis of data obtained can be seen that of the five variables of service quality indicators are established to measure customer satisfaction and have a higher value on main factors, namely tangibles variables strongly influence customer satisfaction in the transaction through the first BNI Syariah Sukabumi.
\end{abstract}

Keywords: Quality of Services, Electronic Delivery Channel. Satisfaction, Customer

\begin{abstract}
ABSTRAK
Penelitian ini bertujuan untuk mengetahui mutu layanan electronic delivery channel di BNI Syariah Sukabumi. Jumlah responden pada penelitian ini sebanyak 30 dengan menggunakan teknik non-probabilitas sampling. Metode yang digunakan adalah metode regresi logistik.Hasil analisis data yang diperoleh dapat diketahui bahwa dari 5 variabel indikator mutu layanan yang terbentuk untuk mengukur kepuasan nasabah dan memiliki nilai lebih tinggi pada faktor utama yaitu variabel tangibles sangat mempengaruhi kepuasan nasabah dalam bertransaksi melalui BNI Syariah Sukabumi.
\end{abstract}

Muhammad Idris. 2016. Analisis Mutu Layanan Electronic Delivery Channel Terhadap Kepuasan Nasabah (2): 160-166

\section{PENDAHULUAN}

Persaingan dunia bisnis menjadi semakin ketat terutama pada lembaga keuangan seperti bank, perusahaan yang ingin maju dan berkembang harus memberikan produk dan jasa yang berkualitas. Saat ini perusahaan dituntut untuk lebih berani dalam berinovasi dan menerapkan strategi agar dapat memenangkan persaingan, tetapi untuk menjadi perusahaan yang unggul di dunia 
bisnis bukanlah sesuatu yang mudah, diperlukan kinerja perusahaan yang maksimal, strategi perusahaan yang baik serta pengelolaan manajemen yang tepat (Setyanto, 2011: 1).

Kesuksesan perusahaan tidak lain adalah perusahaan yang memiliki strategi baru untuk mengatasi masalah atau kerugian yang dihadapi serta menyelaraskan antara strategi dengan kinerja perusahaan, jika kedua hal tersebut bisa diatasi dengan baik maka akan memberikan hasil yang optimal. Keberhasilan perusahaan dalam berkompetisi sangat tergantung pada cara perusahaan memberikan layanan kepada pelanggan. Menurut Anggraeni (2010:1) faktor utama dalam mendapatkan dan mempertahankan pelanggan salah satunya mutu pelayanan, sehingga apabila perusahaan tidak memperhatikan aspekaspek pelayanan maka dapat mengakibatkan berpindahnya pelanggan keperusahaan lain yang dianggap dapat memenuhi keinginan atau kebutuhan pelanggan dalam bertransaksi, jika hal tersebut terjadi tentu akan merugikan pihak perusahaan yang bersangkutan. Salah satu cara untuk memenangkan persaingan adalah dengan memanfaatkan teknologi informasi tidak terkecuali sektor perbankan, kecanggihan teknologi informasi akan mendorong kemajuan produk, kecepatan layanan, efektifitas, efesiansi dan keamanan data yang dimiliki bank tersebut. Oleh karena itu bank harus terus meningkatkan teknologi informasi yang dimiliki agar dapat bersaing di pasar global (Setyanto, 2011: 3).

Teknologi informasi yang dapat diakses dengan cepat sehingga dapat menarik perhatian nasabah, karena pandangan nasabah terhadap suatu bank tidak akan lepas dari nama baik yang melekat pada bank tersebut, salah satunya nasabah memilih bank yang lebih unggul dari kecepatan pelayanan dan kemudahan bertransaksi yang diberikan(Danibrata, 2010:1).

Salah satu teknologi informasi yang digunakan bank pada saat ini adalah Elektronik Delivery Channel yaitu seperti: ATM (Automatic TellerMachine),internet banking, mobile banking, sms banking (PBI No: 9/15/PBI/2007). Dunia perbankan saat ini sudah memanfaatkan internet sebagai salah satu sarana dalam menawarkan berbagai layanan jasa dan produk, sehingga nasabah dapat bertransaksi dengan mudah selama 24 jam. Dengan kemudahan akses tersebut maka nasabah akan memiliki jangkauan layanan yang lebih luas terutama dalam menjalani suatu bisnis.

Disamping kemudahan yang diberikan ternyata bank memiliki risiko dalam menggunakan teknologi informasi, pada satu sisi dapat meningkatkan efisiensi kegiatan operasional, kualitas dan kecepatan pelayanan pada nasabah yang pada akhirnya akan meningkatkan keunggulan bersaing bank tersebut. Sedangkan di sisi lain mengandung risiko potensial, yang apabila tidak diantisipasi dengan baik akan merugikan bank yang bersangkutan.

Menurut Soepraptomo dalam Laraswati (2009:44) adatigajenisrisiko yang dihadapi bank dalam penggunaan teknologi informasi dan komputer. Pertama, environment riskataurisiko yang berasa dari lingkungan intern dan ekstern bank yang meliputi factor loyalitas karyawan dan kesadaran atas pengamanan. Kedua, operation risk atau risiko yang diakibatkan dari kegiatan operasional bank, sehingga semakin besar skala kegiatan yang dikomputerisasikan, maka semakin besar potensi kejahatan yang mungkin muncul. Ketiga, service risk atau risiko yang datang karena bank melansir satu produk atau jasa.

Permasalahan di atas memberikan gambaran bahwa di samping banyaknya 
manfaat dari teknologi informasi tidak sedikit pula risiko yang harus dihadapi, sehingga ini akan berpengaruh tehadap kepuasan nasabah dalam penggunaan Electronic delivery channel yang disediakan oleh bank.

\section{MATERI DAN METODE}

\section{Tinjauan Teoritis}

\section{Indikator Nasabah Dalam Penggunaan E-Banking}

Menurut Nisa Dzurotun (2013 :15) ada beberapa indikator-indikator nasabah dalam penggunaan e-banking yaitu sebagai berikut:

a. Kenyamanan (convenience)

Kenyamanan (convenience) berarti nasabah merasa bahwa electronic delivery channel itu fleksibel dalam hal waktu, tempat dan fasilitas menyediakan tingkat kenyamanan yang lebih tinggi, sehingga dapat memudahkan nasabah untuk bertransaksi kapanpun dan dimanapun.

b. Kemampuan mengakses (accessilability)

Kemampuan mengakses adalah kemampuan untuk mengakses situs dan menghubungi pihak bank ketika dibutuhkan.

c. Ketersediaan Fitur (future availability) Mengidentifikasi faktor lain yang penting di dalam kesuksesan electronic delivery channel, yaitu kemampuan inovasi untuk menghadapi kebutuhan nasabah dengan menggunakan ketersediaan fitur (feature availability) yang berbeda pada website. fitur (feature) berarti hal-hal apa saja yang dapat dilakukan oleh nasabah dengan menggunakan internet banking.

d. Privasi (privacy)

Kerahasiaan (privacy) berarti segala hal yang berhubungan dengan informasi pribadi pengguna terjamin kerahasiaannya, tidak ada orang yang mengetahuinya.

e. Kecepatan

Kecepatan internet banking berguna dalam rangka memberikan informasi yang diinginkan pengguna internet banking. karena hal ini akan menjadi pertimbangan bagi konsumen dalam kecepatan respon speed of response dengan serius ketika berkomunikasi dengan penyedia layanan internet banking.

f. Tarif \& Biaya (fees and charges)

Internet banking memiliki biaya transaksi yang murah dan layanan kecepatan tinggi jika dibandingkan dengan layanan perbankan lain. Kemudian internet bankingdapat memberikan kemudahan kepada para nasabah untuk mengakses akun bank mereka, biaya servis yang lebih rendah, dan mampu menghemat waktu.

g. Manajemen dan Reputasi bank (bank management and image)

Reputasi atau brand reputation didefinisikan sebagai persepsi kualitas, kemudian pada bisnis-bisnis industri dan jasa, nama merk lebih sering dihubungkan dengan reputasi perusahaan dari pada dengan produk atau jasa itu sendiri. Karena itulah salah satu pertimbangan nasabah dalam menabung dan menggunakan jasa bank adalah reputasi perusahaan tersebut, karena kepercayaan merupakan salah satu faktor utama bagi nasabah untuk mempercayakan uangnya ditabung atau diinvestasikan pada bank tersebut.

h. Desain (design)

Desain didefinisikan sebagai tampilan dari internet bankingyang dimiliki bank. Semakin tinggi tingkat komunikasi sosial yang ditampilkan oleh suatu website bank, semakin besar pengaruhnya pada kepercayaan konsumen dan meningkatkan 
kemungkinan konsumen melakukan transaksi online.

i. Konten (content)

Konten merupakan kemampuan internet banking untuk menyediakan informasi yang terbaru mengenai produk maupun jasa terbaru yang ditawarkan

\section{Metode Penelitian}

Jenis penelitian ini merupakan jenis penelitian deskriptif kuantitatif, dengan menggambarkan sifat sesuatu yang tengah berlangsung pada saat penelitian dilakukan dan memeriksa sebab-sebab dari suatu gejala tertentu Sunyoto (2013:31). Penelitian ini bermaksud untuk memberikan gambaran mengenai mutu layanan Electronic Delivery Channel terhadap kepuasan nasabah

\section{Teknik Analisis Data}

Regresi Logistik di mana analisis ini digunakan untuk mengetahui pengaruh mutu layanan Electronic Delivery Channel terhadap kepuasan nasabah BNI Syariah. Menurut (Santoso, 2010:206).

\section{HASIL DAN PEMBAHASAN}

Penelitian ini dilakukan dengan membagikan kuesioner kepada 30 responden, setiap responden tidak hanya menggunakan 1 (satu) Electronic Delivery Channelsaja tetapi diperbolehkan lebih dari 1 (satu). Kemudian dari 30 responden yang menggunakan Electronic Delivery Channel dalam bentuk ATM 30 responden, mobile banking10 responden, sms bangking 11 respodden dan internet bangking 10 respoden. Dengan rata-rata waktu penggunaan lebih dari satu tahun

\section{Uji Reliabilitas dan Validitas}

\section{Uji Reliabilitas}

Uji realiabilitas dari masing-masing faktor menggunakan Crombach's Alpha. Kuesioner dinyatakan reliabel jika mempunyai nilai koefisien alpha yang lebih besar $>0,5$ Hasil penelitian selengkapnya dapat dilihat pada tabel berikut:

\section{Tabel 1. Nilai Statistik Reliabilitas}

\section{Cronbach's N of Items}

Alpha

.885

12

Sumber : Hasil Penelitian (data diolah)

2016

Dari hasil pengujian maka semua instrumen dikatakanreliabel karena nilai koefisien Cronbach Alpha diperoleh lebih besar dari $0,5(\alpha \geq 0,5)$ yaitu sebesar 0,885.Dengan demikian instrumen yang digunakan dalam penelitian ini cukup handal dalam mengukur persepsi responden terhadap variabel yang diteliti dan dapat dilanjutkan ke tahap selanjutnya.

\section{Uji Validitas}

Uji validitas dilakukan untuk menguji kuisioner layak dan digunakan sebagai intrumen penelitian. Valid berarti intrumen tersebut dapat digunakan untuk mengukur apa yang seharusnya diukur. Kriteria dari validitas yaitu bila koefisien korelasi masing-masing peryataan dengan nilai Correected Item Total Correlation lebih besar atau sama dengan nilai $r$ tabel. Maka dinyatakan valid (nilai $r$ tabel dengan responden 30 orang adalah 0,361 ). Hasil uji validitas melalui program SPSS 20.0. 
Dari hasil pengelolahan data, dapat dilihat bahwa koefisien korelasi dari 50 butir pertanyaan yang ada, dikatakan 12 yang valid dengan skor $>0,361$ dan dapat diolah lebih lanjut.

\section{Analisis Data}

Metode analisis data yang digunakan adalah metode analisis regresi logistik dengan bantuan software SPSS Versi 20 for Windows. Untuk lebih jelasnya akan dijelaskan tahapan demi tahapannya.

\section{Analisis Regresi Logistik}

Pada bagian ini akan dilihat pengaruh dari setiap variabel aktivitas mutu layanan electronic delivery channel terhadap

hasil regresi logistik, di manavariabel tangibel memiliki nilai sig. 0,006, Reliabily memiliki nilai sig 0,014, Responsiveness memiliki nilai sig 0,033, Assurance memiliki nilai sig 0,014 < dari 0,050 dan variabel Emphaty 0,074 $>0,050$. Hal tersebut menunjukan bahwa variabel tangible, reliability, responsiveness, assurance berpengaruh secara signifikan terhadap kepuasan nasabah BNI Syariah. sedangkan variabel emphaty berpengaruh secara tidak signifikan terhadap kepuasan nasabah BNI Syariah. Dengan alasan ke empat variabel di atasmemiliki fasilitas

Berdasarkan hasil perhitungan Chi Kuadrat seperti yang ditunjukan pada tabel 4.4 diatas, maka nilai chi kuadrat

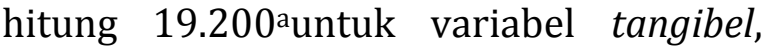
16,133a, variabel reliability, 4,800a, variabel responsiveness $4,800^{\mathrm{a}}$, variabel assurance 16,133 a

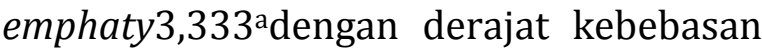
$(\mathrm{dk})=\mathrm{n}-1=2-1=1$. Berdasarkan $\mathrm{dk}=1$ dengan taraf signifikan sebesar 5\%, maka diperoleh chi kuadrat tabel 3.481(terlampir). Diketahui bahwa nilai chi kuadrat hitung lebih besar daripada chi kuadrat tabel $\left(19.200^{a}, 16,133^{a}, 4,800^{a}\right.$, kepuasan nasabah dengan menggunakan analisis regresi logistik, di manapengolahan data dilakukan dengan menggunakan SPSS versi 20. Pengambilan keputusannya sendiri dilihat dari probabilitas Chi Squares, di manajika probabilitas Chi Squares lebih kecil dari tingkat signifikansi $(\alpha=5 \%)$, maka signifikan dan sebaliknya jika Chi Squares lebih besar dari tingkat signifikansi $(\alpha=$ $5 \%$ ), maka tidak signifikan (Widarjono, 147 : 2010). Untuk interpretasi dilakukan lewat angka Odds ratio, dimana dalam SPSS versi 20 terdapat pada kolom Exp (B). (Widarjono: 142: 2010).

Berikut tabel hasil Uji Regresi Logistik:

yang lengkap, pihak bank segera memberi bantuan apabila ada kendala dalam penggunaan electronic delivery channel serta electronic delivery channel dapat diandalkan dalam bertransaksi di bank dan memberi keamanan data yang dimiliki nasabah. Adapun variabel emphaty tidak terlalu berpengaruh terhadap kepuasan nasabah BNI Syariah Sukabumi karena penjelasan mengenai electronic delivery channel terlalu cepat sehingga nasabah tidak terlalu paham terhadap penjelasan tersebut.

4,800a , dan $16,133^{\mathrm{a}}>$ 3.481) dengan demikian $\mathrm{H}_{1}$ diterima dan $\mathrm{H}_{0}$ ditolak diterima atau dapat dikatakan bahwa pertanyaan tangible, reliability, responsiveness, dan assurance berpengaruh terhadap kepuasan nasabah BNI Syariah Sukabumi. Sedangkan variable emphaty nilai Chi kuadrat hitung lebih besar daripada chi kuadrat tabel $\left(3,333^{\mathrm{a}}>\right.$ 3.481) dengan demikian $\mathrm{H}_{1}$ ditolak dan $\mathrm{H}_{0}$ diterima atau dapat dikatakan bahwa pertanyaan emphatytidak berpengaruh terhadap kepuasan nasabah BNI Syariah 
Sukabumi,karena penjelasan mengenai Electronic Delivery Channel terlalu cepat sehingga nasabah tidak sepenuhnya mengerti tentang Electronic DeliveryChannel BNI Syariah

\section{KESIMPULAN DAN IMPLIKASI}

Berdasarkan penelitian yang telah dilakukan terhadap kepuasan nasabah BNI Syariah terhadap mutu layanan electonic Delivery channel, maka kesimpulan yang dapat dihasilkan adalah sebagai berikut:

1. Langkah-langkah pengguanaan electronic delivery channel BNI Syariah dalam penelitian ini dibagi dalam beberapa bentuk yaitu tahapan pengguanaan internet banking, penggunaan sms banking, mobile banking, dan pengguanaan ATM. Adapun tahapan penggunaan internet banking dan sms banking tidak jauh berbeda yaitu bisa registrasi melalui ATM BNI Syariah atau customer service dengan prosedur yang disyaratkan. Lalu tahapan penggunaan mobile banking BNI Syariah ini merupakan layanan e-banking berbentuk aplikasi smartphone, maka ada 2 tahapan yang harus dilakukan untuk dapat memanfaatkan fasilitas $e$ banking BNI Syariah.

2. Dari hasil analisis data yang dilakukan dapat diketahui bahwa dari 5 variabel yang diteliti, untuk variabel tangibles merupakan variabel yang paling tinggi nilai sig. 0,006 < 0,05 yang berarti variebel tangibles sangat berpengaruh terhadap kepuasan nasabah BNI Syariah. dan variabel yang paling rendah nilai signifikannya yaitu variabel emphaty yaitu dengan nilai $0.074>0,050$ sehingga tidak terlalu berpengaruh terhadap kepuasan nasabah.

\section{DAFTAR PUSTAKA}

Ahmad, Setyanto. 2011. Pengaruh kualitas pelayanan terhadap kepuasan nasabah dan loyalitas nasabah tabungan Britama pada Bank BRI Samarinda. Fakultas Ekonomika Dan Bisnis Universitas Diponegoro Semarang.

Al-Sukkar and Hasan H. 2005. Toward a Model for the Acceptance of Internet Banking in Developing Countries. Information Technology for Development, Vol 11., No.4, pp. 381 $-398$.

Danibrata. 2010. Pengaruh Kualitas Pelayanan Teller Terhadap Kepuasan Nasabah Jakarta Pada PT. Bank Rakyat indonesia.

Dzurotunnisa. 2013. Pengaruh Kualitas Layanan terhadap Kepuasan Pelanggan dalam Membentuk Loyalitas Pelanggan. Sekolah Tinggi Ilmu Ekonomi Widya Manggala.

Exmawati. 2014. Pengaruh Kualitas Layanan, Kualitas Produk dan Nilai Nasabah Terhadap Kepuasan dan Loyalitas Nasabah Bank Mandiri Departemen Manajemen Fakultas Ekonomi Manajemen. Institut Pertanian Bogor.

Fandy, Tjiptono, dan Gregorius Chandra. 2011. Service Quality and Satisfaction (ed 3). Yogyakarta.

F.hair. Joseph. 2006. Multivariate Data Analysis, Pearson Prentice Hall, 2006

Gujarati. 2000. Analisa Kualitas Pelayanan Terhadap Kepuasan Nasabah Pada Pt.Bank Btpn Kanca Manado Metode Penelitian Untuk Menulis Skripsi Dan Tesis, Jakarta: PPM.

Gani, Irwan dkk, 2015, Alat Analisis Data : Aplikasi Statistik untuk Penelitian Bidang Ekonomi dan Sosial. Penerbit Andi : Yogyakarta

Hessen. 2005. Analisis Pemetaan Persepsi Nasabah Terhadap Elektronic 
banking Channel Bank Bri. Jurnal Analisis Volume XI, Nomor 2, Desember

Hidayat. 2004. Persepsi Nasabah terhadap Penerapan Sistem Layanan Produk dan Jasa E-Banking.Jurnal aplikasi manajemen, Volume 8, No. 2, September 2004; 76-80

Hasan, Maulana. 2013. Menciptakan Kepuasan Dan Loyalitas Pelanggan Melalui Citra Dan Service Recovery. Jurnal Bisnis dan Ekonomi (JBE), Maret 2013, Hal. 93 - 109.

Kevin. Lane Keller., 2003, Strategic Brand Manajemen, Second Edition, Prentice Hall

Kotler, Philip dan Kevin Lane Keller., 2007, Manajemen Pemasaran, Edisi Kedua Belas, Jilid 2, dialih bahasakan oleh Benjamin Molan, Jakarta: PT Indeks.

Laraswati. 2009. Analisis pemetaan persepsi nasabah terhadap elektronic banking channel Bank BRI.Jakarta : Binarupa Aksara.

Lestariningsih. 2011. Peran Produk Perbankan, Mutu Pelayanan dan Kepuasan Nasabah bagi Kinerja PT Bank Negara Indonesia (Persero) Tbk. di KCU Utama Jakarta.

Peraturan Bank Indonesia Nomor: 9/15/Pbi/2007 Tentang Penerapan Manajemen Risiko Dalam Penggunaan Teknologi Informasi Oleh Bank Umum.
Rahardjo, Budi. Aspek Teknologi Dan Keamanan Dalam Internet Banking, Indocisc, 2001.

Sunyoto. 2013. Analisis Faktor Kualitas Pelayanan Di Bank Syariah 2011. Jurnal aplikasi manajemen, Volume 9, No. 6, September 2013; 76-80.

Sofhiana. 2011. Pengaruh Kualitas Layanan Terhadap Tingkat Kepuasan Nasabah. Jurnal Aplikasi Manajemen | Volume 10 | Nomor 2 | Juni 2011

Santoso. Singgih. 2010. Statistik Mulitvariat. PT Alex media komputindo, Jakarta 2010

Puji, Septin, Wiwik. Wilasari, Datien. Eriska Utami. 2009. Meningkatkan Kualitas Pelayanan Di Bank Syariah. Jurnal Manajemen Bisnis |Vol. 2 No. 1 |April - Juli 2009 (47 58)

Tjiptono, Diana. 2000. Analisis FaktorFaktor Yang Mempengaruhi Nasabah Menggunakan Layanan Internet Banking Mandiri. Program Studi Muamalat (Ekonomi Islam), Universitas Islam Syarif Hidayatullah.

Youni, Sari. 2013. Pengaruh Dimensi Kualitas Pelayanan Jasa Terhadap Kepuasan PelangganD\&I Skin Centre Denpasar. Jurnal aplikasi manajemen No.21/Tahun Ke12/Desember 